DOI https://doi.org/10.30525/978-9934-588-79-2-2.17

\title{
ВИКОРИСТАННЯ ВІДХОДІВ РОСЛИННОЇ СИРОВИНИ В ТЕХНОЛОГІЇ СОЛОДКИХ ЖЕЛЬОВАНИХ СТРАВ
}

\author{
Горобець О. М. \\ кандидат технічних наук, \\ дочент кафедри технологій харчових виробництв \\ і ресторанного господарства \\ Вищого навчального закладу Укоопспілки \\ «Полтавський університет економіки і торгівлі» \\ Левченко Ю. В. \\ кандидат технічних наук, \\ доцент кафедри технологій харчових виробництв \\ і ресторанного господарства \\ Вищого навчального закладу Укоопспілки \\ «Полтавський університет економіки і торгівлі» \\ м. Полтава, Украӥна
}

Концептуальні зміни в харчуванні стають основою технологічних розробок. У зв'язку з цим з'являється необхідність у створенні нових харчових систем, збалансованих за мікро- та макронутрієнтами і таких, що можна адаптувати під різні смаки споживачів. Особливу популярність мають харчові продукти на основі гелеутворювачів.

Одним із перспективних та стратегічних сировинних ресурсів, що використовується в якості гелеутворювача є пектин, який володіє унікальними комплексоутворювальними властивостями, що позитивно впливають на холестериновий обмін в організмі, регулюють моторну функцію кішківника, стабілізують $\mathrm{pH}$, врівноважують мінеральний склад та покращують якість мікрофлори шлунково-кишкового тракту, підвищуючи тим самим стійкість організму до дії алергенів та вірусів.

Використання пектину як гелеутворювача у виробництві харчової продукції має наукове та практичне значення.

Широкий асортимент пектинів, що наразі існує, дозволяє одержати харчові системи з різними реологічними властивостями: від в'язко текучої неньютонівської рідини до щільного зміцненого або пружнопластичного гелю. Крім того, пектини володіють низкою технологічних властивостей, зокрема високою вологоутримувальною здатністю та тривалою стабільністю утворених систем. 
Серед широкого асортименту продукції закладів ресторанного господарства особливу групу складає желеподібна десертна продукція, аналіз ринку якої вказує на перспективність розширення асортименту, просування ії на продовольчий ринок України за підтримки фундаментальних і прикладних досліджень у цій галузі.

Проте недостатній рівень індустріальної виробничої бази, широкого впровадження новітнього наукового доробку харчової науки, а також стійкі тенденції залучення до виробництва желейної продукції імпортних гелеутворювачів, зокрема на основі агару, фурцеларану, желатину, спонукає до пошуку сучасних вітчизняних джерел, до яких відноситься пектин, а для зв'язування і одержання твердих і пружних гелів цілком доцільно ви-користовувати жельовані соки, які є продуктами переробки відходів рослинної сировини [1, с. 110 2, с. 18].

Плоди і ягоди, що активно культивуються на території Україні, i характеризуються високим вмістом природних біологічно активних речовин, у тому числі пектинових речовин та харчових волокон, можуть бути джерелом природних гелеутворювачів.

Дослідженнями функціонально-технологічних властивостей нетрадиційної сировини займалися вітчизняні та зарубіжні вчені, зокрема, Малюк Л.П, Павлюк Р. Ю., Дудкін М.С., Щелкунов Л.Ф., Барабой В.А., Корячкіна С.Я., Василенко 3.В. та інші [3, с. 15, 4, с. 254, 5 с. 124]. Теоретичні основи та практичні аспекти виробництва харчової продукції на основі гелів досліджувались у наукових школа українських вчених Пивоварова П.П., Перцевого Ф.В., Гринченко О.О.

Однак, проведені дослідження практично не стосувалися використання в якості гелів пектинових речовин, джерелом яких є рослинна сировина, зокрема, продукти переробки ягід порічок в технології виробництва жельованих десертів.

Порічка є цінним джерелом вітамінів (C, Р, групи В), мінеральних речовин (йод, залізо, калій, кальцій, магній, фосфор, цинк), а також органічних кислот, пантотенової, фолієвої кислот, кумарину, пектину, танінів та азотистих речовин.

Порічки вважаєтюся одним з продуктів, які слугують профілактикою онкологічних захворювань.

При переробці порічок на пюре залишаються вичавки, які містять в своєму складі пектинові речовини органічні кислоти барвні та ароматичні речовин, що доводять їх перспективність для використання в продуктах харчування. Найбільш раціональним є використання вичавок для отримання желюючого соку. 
Для отримання желюючого соку вичавки з порічок з'єднували 3 водою у співвідношенні 1:2, піддавали термічній обробці протягом 30 хвилин, охолоджували та проціджували.

Визначено, що масова частка пектинових речовин в отриманому желюючому соці вища у порівнянні з соком 3 порічок і його можна використати для отримання желейних страв. Окрім того, желюючий сік містить у своєму складі значний вміст фенольних речовин, що позитивно впливає на його біологічну цінність.

Виготовлений желюючий сік використовували в рецептурі десертів на желейній основі таких самбук та пана-кота і досліджували зміну структурно-механічних властивостей та фізико-хімічних показників десертів.

В процесі експериментального дослідження визначали частку желюючого соку, який доцільно вводити в рецептуру. 3 цією метою досліджували вплив желюючого соку в кількості $25 \%$, 50 \%, та 75 \% від розрахункової кількості желатину.

За результатами досліджень встановили оптимальну кількість желюючого соку в десертах - 75 \% від розрахункової кількості желатину. Визначено, що подальше збільшення приводить до зниження міцності желе.

Для дослідження реологічних властивостей десертів визначали показник пружної деформації желе методом одноосного стиснення при температурі $20^{\circ} \mathrm{C}$ і навантаженні 30 г.

Отже за структурно-механічними властивостями, в порівнянні 3 контролем, самбук та пана-кота, які містять більше $75 \%$ желюючого соку мають нижчі показники пружності, тобто вироби чинять менший опір впливу зовнішніх сил. Спостерігається збільшення еластичності в зразках з внесенням 75 \% желюючого соку, що свідчить про кращу здатність желе витримувати зворотні деформації без руйнування протягом певного періоду. Цю ж властивість підтверджують показники пластичності.

В дослідних зразках солодких страв визначали органолептичну оцінку та розраховували показник якості виробів. За результатами профільного аналізу встановлено, що дослідні зразки з додаванням $50 \%$ желюючого соку характеризуються вищими показниками за критеріями: смак, колір, однорідність. Таким чином, використання желюючого соку в технології пана-коти та самбуку дає можливість отримати готовий виріб з покращеними органолептичними показниками.

Підтверджено можливість подовження тривалості зберігання десертів протягом доби без зміни їх початкових реологічних властивостей. 
Протягом зберігання загальна залежність відносних показників розроблених десертів 3 желюючим соком не змінилася у порівнянні з контролем. Вироби характеризується вищими показниками пружності, пластичності та еластичності.

Досліджено мікробіологічні показники якості десертів і встановлено, що солодкі десерти відповідають санітарно-гігієнічним регламентованим нормам і можуть бути рекомендовані для широкого впровадження в закладах ресторанного господарства.

Отже, додавання желюючого соку до рецептури дозволяє не лише зменшити частину желатину на желюючий сік, а й підвищити біологічну цінність десертів та покращити їх органолептичні властивості.

\section{Література:}

1. Гницевич В. А., Федотова Н. А. Определение свойств самбуков на основе белково-растительного полуфабриката из молочной сыворотки. Технические науки - Информатика, вычислительная техника и автоматизация. 2011. № 40 (10). С. 109-124.

2. Левченко Ю.В, Хомич Г.П., Горобець О.М. Розробка технології солодких страв і оздоблювальних напівфабрикатів. Нові технології $i$ обладнання харчових виробництв: матеріали Міжвузівського науковопрактичного семінару., м. Полтава, 18 квітня 2019 р. Полтава, 2019. C. $18-20$.

3. Шевченко О. В. Технологія солодких страв і соусів із вітапектином та фітосорбентом: автореф. дис...канд.техн.наук 05.18.16. Київ, 2002. $20 \mathrm{c}$.

4. Гніцевич В. А. Наукове обгрунтування технологій кулінарної продукції з пінною й емульсійною структурою з використанням амаранту та топінамбуру: дис. ... д-ра техн. наук: 05.18.16. Київ, 2010. $321 \mathrm{c}$.

5. Грищенко С. В. Застосування напівфабрикатів 3 дикорослих плодів та ягід для подовження терміну придатності кондитерських виробів. Ресурсо- та енергоощадні технології виробнищтва і пакування харчової продукиії - основні засади ї̈ конкурентоздатності: матеріали V Міжнародної спеціалізованої науково-практичної конференції, м. Київ, 14 вересня 2016 р. Київ, 2016. С. 124-125. 